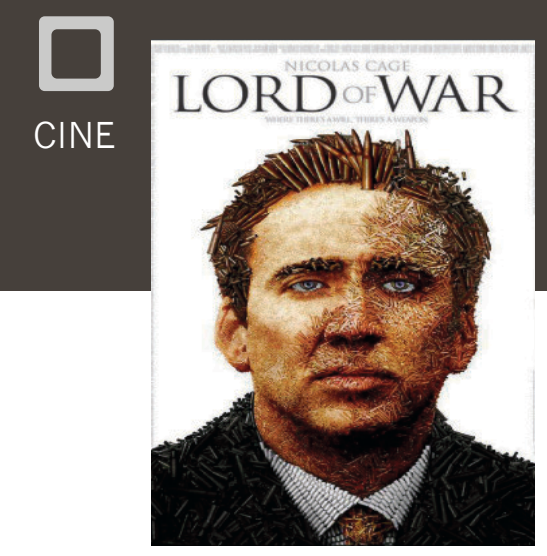

TÍTULO ORIGINAL,

"Lord of War" (EI señor de la guerra)

AÑO: 2005, DURACIÓN: 122 minutos,

PAÍS: Estados Unidos,

DIRECTOR: Andrew Niccol

GUIÓN: Andrew Niccol

MÚSICA: Antonio Pinto,

FOTOGRAFÍA: Amir M. Mokri,

REPARTO: Nicolas Cage, Ethan Hawke, Bridget

Moynahan, Jared Leto, Ian Holm, Eamonn

Walker, Jean-Pierre Nshanian, Sammi Rotibi,

Shake Tukhmanyan,

PRODUCTORA: Lions Gate Films,

GÉNERO: Thriller, acción, drama

\title{
El señor de la guerra
}

La guerra es un acontecimiento histórico que ha estado presente desde los albores de la humanidad, las causas y las condiciones de su surgimiento ha dado origen a disciplinas científicas contemporáneas como la polemología y los Estudios Estratégicos que han logrado sistematizar programas de investigación para su estudio y análisis minucioso. En cualquier latitud y tipo de sociedad, la guerra ha tenido diversas modalidades ocasionando distintos números de víctimas, enfrentando una determinada cantidad de actores armados, mostrando violencia extrema, durado todo tipo de tiempo, presentando patrones a cual grado más sorprendente de complejidad, un fenómeno social que se ha intentado reglar, limitar, prevenir e incluso justificar. En la guerra se han desplegado estrategias, ingenio tecnológico, armamentos simples y sofisticados; pero todo igual de mortíferos.

Los siglos $X X$ y XXI, han constituido épocas en donde han proliferado guerras civiles, muchas de ellas con raíces en la conflictividad interétnica, mientras que otras han estado dirigidas al derrocamiento de regímenes que no se apreciaban como legítimas.

A principios y mediados de los años noventa, período conocido como la post guerra fría; los ideólogos ultra liberales proclamaron la tesis del fin de la historia, el momento decisivo de la victoria sistémica final del capitalismo; en su conjunto, una visión que fue incapaz de organizar la economía mundial en el imperativo de la prevención de conflictos armados internacionales, tal y como lo proponían las tecnocracias de las organizaciones mundiales en materia y en el objetivo de procuración de la paz internacional.

Es en todo este contexto que surgieron cruentas guerras o conflictos armados en el África Occidental, una subregión que permaneció en paz durante el auge y vigencia de la guerra fría. Se trata de países como Liberia y Sierra Leona con guerras internas cuyas características dieron cuenta de la ausencia de causas políticas legítimas o justificadas; la violencia armada adquirió connotaciones privadas, es decir, pequeños caudillos o líderes tribales de grupos étnicos mayoritarios que se hicieron del control de territorios con abundancia de recursos estratégicos relacionados a la explotación minera. 
Estos grupos armados desarrollaron una economía ilícita que fortaleció el tráfico clandestino de diamantes con todo y las implicaciones logísticas y de contra demanda de armas de fuego, instrumento base para retener el control militar de zonas estratégicas de potencial actividad extractiva.

El estado de guerra en estas sociedades del África Occidental plantó economías subterráneas basadas en la esclavización de población rural que fue desplazada de sus lugares de origen y sometida a sistemas de trabajo extenuantes con jornadas prolongadas; huir de estos secuestros colectivos constituyó la única alternativa para muchos, pero implicó migración masiva que complicó a las ciudades bajo control gubernamental ya exiguas en servicios públicos. Esta economía de guerra también se nutrió del reclutamiento forzoso de niños soldados, quienes fueron utilizados para ejercer el terror contra los rivales; de esto último dio cuenta la difundida práctica de las fuerzas irregulares de amputar los miembros superiores de los rivales o de todos aquellos que se oponían al reclutamiento con ello se afectó la productividad de las zonas rurales y cargó a los Estados en los menesteres de atención a discapacitados.

El señor de la guerra, presenta a un Nicolás Cage en el papel de Yuri Orlov, un traficante de armas ruso, que dispone abundantemente de las mismas y que junto a su hermano planean audaces operaciones de entrega a los caudillos del África Occidental, que se encuentran entre sus principales clientes. Estos embarques clandestinos frecuentes violan los dispositivos de embargo de la Naciones Unidas, que se vuelven infuncionales ante las demandas de armas de los bandos enfrentados y la disponibilidad inescrupulosa de los proveedores, entre ellos los hermanos Orlov.

Del film pueden advertirse aspectos fundamentales que permiten un excelente acercamiento al tráfico de armas. Uno de ellos concierne a la realidad internacional de la post guerra fría, es decir; de cómo la fragmentación nacional en el espacio post soviético, la transición de las economías de guerra y el emprendedurismo armamentístico; se convirtieron en un factor clave para el reabastecimiento de armas hacia grupos armados, en lejanos conflictos de países periféricos.

Se trata de un contexto de tránsito de la economía de esos países, en donde los procesos de privatización propiciaron brechas de corrupción y de enriquecimiento ilícito que empoderaron a antiguos burócratas erigiéndolos como hombres adinerados que se hicieron de importantes acciones en las empresas públicas privatizadas. Más abajo de las jerarquías proliferaron operarios y ejecutivos en el oficio de traficantes, de estas filas proviene Orlov, para quien negociar con armas es una forma más de ganarse la vida y ascender socialmente.

Un segundo aspecto mostrado en el film es la moral del traficante, la película desarrolla un estilo satírico acerca de lo que se presenta como complicaciones y paradojas en estos negocios oscuros, Yuri Orlov ostenta un estilo de vida, en el 
cual todo está resuelto; menos la aceptación de la familia inmediata que reprueba las actividades a las que se dedica, y que él insiste en defender como un negocio legítimo y normal; y que promete abandonar pronto.

El tercer aspecto, retrata al receptor de las armas de guerra; generalmente caudillos brutales ensimismados por su propia avaricia e intereses privados, que siembran el terror entre los campos de desplazados y otras poblaciones aisladas y que distan mucho de defender causas políticas legítimas. En medio de esa tragedia, el relato evidencia las condiciones extremas de la cultura de escasez de estas sociedades africanas. De esto último llama la atención la escena en donde Yuri Orlov hace una entrega de un cargamento de armas en un viejo avión Antonov-22; el cual se vio obligado a aterrizarlo de emergencia.

El avión abandonado en una rústica pista en medio del campo, es saqueado numerosas veces por delincuentes locales y su fuselaje va siendo paulatinamente desmontado por personas comunes y corrientes que advierten en cada objeto, un valor diverso, desde vender chatarra hasta usos habituales a manera de enseres.

Finalmente el film revela que las tramas que se suceden en el tráfico de armas son complejas y que intervienen factores de diversas índole que la fomentan y la reproducen, mostrando en el proceso la dificultad de que sociedades desvastadas por la guerra regresen a la normalidad. Recuperar las armas es más complicado, es como una mina antipersonal de tipo artesanal cuyo costo es de un dólar; pero su ubicación, desactivación o destrucción puede demandar hasta más de tres mil dólares.

Sinopsis a cargo de Juan Carlos Morales Peña Coordinador Principal del Centro de Investigación Científica CINC-ANSP 